\title{
Transnational families in Spain. Marriage, nationality and gender
}

The paper is dedicated to immigration and transnational families in Spain. The author presents legislative aspects, discusses social phenomena and analyzes crucial INE data which hinge on the intersection of immigration and family issues. The data include: $1 /$ the number of marriages which are referred to as matrimonios mixtos, i.e. the ones which are contracted between a Spaniard and the other spouse being a foreigner, 2/the number of marriages contracted in Spain between foreigners and 3/their share in the total number of nuptials. Legislative aspects relate to the formal conditions which need to be fulfilled by foreigners in order to enter into wedlock and the requirements concerning documentation on the part of a Spanish citizen and a foreigner. What is important, the Spanish law allows a marriage to be contracted between a Spanish citizen and a foreigner regardless of the status of the latter. That is to say, the future spouse may be in a so-called irregular situation which grants the right for undocumented immigrants to get married in Spain and eventually obtain a residence permit.

Keywords: Spain, transnational families, immigration, (un)documented immigrants, different/same-sex marriages, legislation, nuptials

Patterns upon which a family is constructed may reach beyond borders with respect to the place its members proceed from or dwell. This is even more so with, on one hand, the increased geographic mobility of individuals and, on the other, structural opportunities, including national policies, international treaties, formation of supranational entities allowing citizens of their member states to cross borders

${ }^{1}$ Contact: mmbiernacka@tlen.pl 
without restrictions ${ }^{2}$. In such instances, a transnational family is the prime concept to be put into action. It is worth mentioning an alternative concept of the world family which has been used by Ulrich Beck and Elisabeth Beck-Gernsheim (2014), who analyze it in the context of globalization of love and intimacy along five dimensions: distant other in the family, cross-border communication, global inequalities, conflicting legal systems, and clashing ideals in families. The authors distinguish two ideal types of such families, one being multilocal and the other one-nation. They introduce a term multilocal world family with reference to a family whose members live in different countries. On the contrary, the notion one-nation family is proposed to denote families which are made up by individuals who come from different countries but live in the same country. These are ideal types rather than a reflection of social reality, in which these patterns intertwine and are dynamic rather than static. While people migrate to get a new lease of life elsewhere or are displaced against their will, their families do not remain unchanged. As they leave their kindred behind or bring some relatives with them, family networks are deconstructed and reconstructed - which in many cases happens repeatedly and takes on various forms.

Transnational families have become an interesting object of study in a number of geographical, political, cultural and social contexts, both in historical and contemporary perspectives (e.g. Orellana, Thorne, Chee and Lam 2001, Bryceson and Vuorela, eds. 2002, Hirsch 2003, Salazar Parreñas 2005, Schmalzbauer 2005, Goulbourne, Reynolds, Solomos and Zontini 2010, Zontini 2010, Johnson, Sabean, Warren, Teuscher and Trivellato, eds.: 2011, Madianou and Miller 2012, Tyrrell, White, Ní Laoire and Carpena-Méndez, eds., 2013, Heidbrink 2014, Baldassar and Merla, ed.: 2014, Sportel 2016, Yarris 2017, Francisco-Menchavez 2018). They have become a commonplace phenomenon in the countries with high immigration rates such as just to give a few European examples: Great Britain, Germany, Sweden, The Netherlands, Belgium, France, Italy or Spain, but also the ones which are characterized by high rates of emigration - as some family members, like grandparents or children remain there while others relocate, like in the case of Poland (e.g. Bell and Erdal 2015: 77-98, Slany, Ślusarczyk, Pustułka and Guribye, eds. 2018), Romania (e.g. Hărăgus,, Telegdi-Csetri 2018: 161-177) and other Central and Eastern European countries.

2 There is a long-standing discussion concerning theoretical frameworks of migratory processes. A rough division can be made between macro, micro and middle-range propositions (e.g. Ai-hsuan 2000: 145-184). However, the macro theories seem to predominate in this field of study. Among the most successful conceptualizations which triggered their intensive development are the ones that are based on the interplay between pull-and-push factors (see: Lee 1966: 47-57). That is an overall term for the factors which make some places or countries attractive to newcomers on the grounds of better work and quality-of-life opportunities, benign climate or chances of a peaceful life - these are called pull factors, while the ones referred to as push factors force people to leave. Examples of the latter are: saturated labor markets, wartime, extreme violence, political oppression, religious, racial or ethnic persecutions, famine, drought etc. Thereupon, not only economic migration and human capital flight or brain drain take place, but also other phenomena, including illegal migration and seeking political asylum. 
When it comes to the Spanish society, transnational families are common especially in the metropolitan areas of Madrid and Barcelona, the southern mainland bordered by the Mediterranean Sea and the two archipelagoes, i.e. the Balearic Islands in its basin and the Canary Islands in the Atlantic Ocean off the African coast. This is due to a number of factors, including the inflow of migrants to Spain which have vastly transformed its social fabric over the recent decades ${ }^{3}$, and legal possibilities for transnational family formation, including family reunification ${ }^{4}$. There are a large number of marriages contracted in Spain with at least one spouse being a foreigner.

The contribution is to analyze selected legislative aspects and present $\mathrm{INE}^{5}$ data which hinge on the intersection of family issues and immigration. The crucial ones include (1) the total number of nuptials and (2) the number of marriages which are contracted in Spain with at least one spouse being a foreigner. Even though the main readership of the article is Polish, the aim is not to present the data referring to Polish foreign spouses in Spain but to cover the entire panorama and trends. For one thing, the number of Polish foreign spouses is relatively small. For another, the topic is adequate for a separate article, including the socio-demographic situation of Polish migrants in Spain and its dynamics (see e.g. Kaczmarczyk, Stanek 2016: 69-100).

Although there are other ways of transnational family formation, including formalized and non-formalized cohabitation or adoption, social and legal bonds formed by contracting a marriage remain the fundamental ones and there is a tractable body of data with respect to them at the national level. I have collated these from databases with reference to the years 1996-2014 which is the entire time span

${ }^{3}$ The share of the foreign populace in the Spanish society had been growing steadily until 2011. While in the early 1980 s the percentage of foreigners was around a mere 0,5 per cent, it reached a few per cent in the early 2000s and doubled later in the same decade. At the beginning of the new decade it reached over 12 per cent (in the year 2010 it was 12.2 per cent, in 2011 - similarly 12,2 per cent) which is the highest percentage observable in this period. Since 2012 we can observe a decrease which is attributed to a number of factors, including a severe economic crisis which started in the year 2008 . It made Spain less attractive as a destination for immigrants and contributed to their remigration and emigration of Spaniards. Another factor which should not be neglected is the naturalization of immigrants which decreases the share of the foreign populace in the society. According to provisional INE data as of the 1st of January 2016 the population of Spain was 46.524 .943 which is less by 99.439 in comparison to the 1st of January 2015. Out of the total, 41.923 .671 have Spanish nationality and 4.601.272 are foreigners, which is 9,9 per cent of the entire population (INE 2016a: 1). These data certainly do not include undocumented individuals who reside on the Spanish territory.

${ }^{4}$ There is vast literature on legal aspects of family reunification in Spain e.g. Arrese Iriondo (2010: 79-107), Freire Correia de Gusmao (2010: 113-160), La Spina (2011), Pérez-Nievas Montiel and Vintila (2011: 143-169), Gozálvez Pérez (2012: 150-162), Martín Villegas (2015: 39-55). These include discussions on the amendments of the law with respect to the rules upon which family members could be reunified in Spain. With the adoption of the new law, i.e. Ley Orgánica 2/2009 as of the 11th of December, provisions were added stipulating the requirements which individuals have to meet in order to be eligible for the procedure of family reunification.

${ }^{5}$ abbrev. of Instituto Nacional de Estadística (Eng. National Statistics Institute, otherwise translated as Spanish Statistical Office). 
made available by INE at the time of writing this article, and starting from the year 2005 when same-sex marriages became legalized, nuptials contracted between men and those contracted between women. When it comes to legislative aspects, I relate to the formal conditions which need to be fulfilled by foreigners in order to enter into wedlock and the requirements concerning documentation to be presented by a Spanish citizen and a foreigner. What is important, the Spanish law allows a marriage to be contracted between a Spanish citizen and a foreigner regardless of the status of the latter. That is to say, the future spouse may be in a so-called irregular situation which grants the right for undocumented immigrants to get married in Spain and eventually obtain a residence permit.

\section{Marriages contracted by foreigners in Spain and their legal status}

A Spanish citizen and a foreigner have the right to contract a marriage in Spain, regardless of the legal status of the latter ${ }^{6}$. That is to say, it is possible for a Spaniard to contract a marriage with a so-called extranjero en situación irregular, i.e. 'foreigner in irregular situation. This category refers to individuals who, being neither citizens of Spain nor another European Union member state, do not possess authorization to sojourn in Spain. That includes those who entered illegally and have not legalized their stay, entered legally but have overstayed, i.e. exceeded their stay over the time limit prescribed by the visa requirements. Such a condition is referred to as irregularidad sobrevenida which literally means 'prolonged irregularity'. It also relates to individuals who have not applied for a visa or residence permit, even though the law imposes such a requirement on them or did apply but have been denied it. The category of a foreigner in irregular situation is pivotal in day-to-day activity of public administration officials at all levels, the police forces and other bodies which are empowered to limit civil disobedience. It is also commonly recognized by Spaniards as it has been resonating over recent years both in political discourse and mass media with reference to immigration and the so-called refugee crisis.

While there are sanctions regarding irregular sojourn on the Spanish territory for non-EU citizens, including fines, deportation and a five year re-entry ban, the law is much more lenient when it comes to formalizing one's status via marriage. The leeway is granted if one of the future spouses is Spanish and wishes to contract

${ }^{6}$ Foreigners are granted the right to family life under Article 16.1 of the Law 4/2000, as of the 11th of January, on the rights and liberties of foreigners in Spain and their social integration (Ley Orgánica 4/2000, de 11 de enero, sobre derechos y libertades de los extranjeros en España y su integración social). This article is a vital point of reference when contracting a marriage and may be applicable when other legal forms of forming and maintaining a family are concerned, including family reintegration (with respect to family reintegration see also Article 16.2 and 17.1-17.3 of the same Law). The link to the complete text of the law is provided at the end of the paper in the section: Other sources. 
a marriage with a foreigner in an irregular situation. In order to do so, both parties should present the required documents in the local civil register, including the ones that certify their legal capacity to contract a marriage, i.e. marriageable age and their status as being unmarried, i.e. either single, divorced or widowed. By contracting a marriage with a Spanish citizen, a foreigner who is not an EU citizen, is an undocumented immigrant or political refugee obtains the status of familiar de un ciudadano comunitario, i.e. a family member of an EU citizen. Thereupon, he or she may apply for a residence permit.

\section{Marriage and foreign status in different-sex and same-sex marriages. Statistical data and trends in the years 1996-2014}

There are statistical data available on the numbers of marriages contracted in Spain with at least one spouse being a foreigner. These are aggregated by INE within the section La Estadística de Matrimonios, i.e. the Statistics of Nuptials ${ }^{7}$ via statistical bulletins of nuptials (boletines estadísticos de matrimonio) at the level of autonomous communities and for that purpose collected on the basis of civil registers ${ }^{8}$ within those administrative units. While analyzing the scale of marriages contracted with at least one spouse being a foreigner it is worthwhile to look at the data in a wider perspective and take into account the overall number of nuptials. When analyzed in the years since 1996, there has clearly been a declining trend in the number of marriages which were contracted annually in Spain. It is worth noting that in mid-2005 there was a substantial legislative change in terms of the gender of spouses when a law was approved allowing same-sex marriages ${ }^{9}$. Thus, from that year onwards data concerning same-sex nuptials are incorporated in the national statistics. These data are quite detailed: not only are gay and lesbian nuptials subsumed under separate categories but that is also done with reference to the ones within each of those groupings that are contracted with at least one spouse being a foreigner. It is a pragmatic consequence of the legislative change in data analysis that numbers concerning different-sex and same-sex nuptials are provided separately in the INE base, also with a division within the latter category between the ones contracted between men and the ones contracted between women. I am

${ }^{7}$ It is part of Las Estadísticas del Movimiento Natural de la Población (literal translation to English: The statistics on the natural movement of the population).

8 in Spanish: registros civiles.

9 i.e. the Law 13/2000 of the 13th of July which amends the Spanish Civil Code with respect to the right to marry. This law was passed as a consequence of a legislative initiative of the Spanish Socialist Workers' Party (original name: Partido Socialista Obrero Español, abbrev. PSOE). It was an important part of its electoral programme and a subject of dissent on the part of the right-wing People's Party (orig. Partido Popular, abbrev. PP). The link to the complete text of the law is provided at the end of the paper in the section: Other sources. 
collating them for the purpose of a presentation of the total numbers of marriages and an exposition of general trends. While the number of marriages which were contracted in the year 1996 amounted to 194.084, in the year 2014 it was only 159.279 when it comes to the ones contracted between men and women, and 162.554 if same-sex nuptials are added. Even though there was a certain increase in the first half of the 2000s in the number of nuptials, the data concerning subsequent years show a steady decline both in the number of heterosexual nuptials and the total number of nuptials, to a certain extent augmented by same-sex marriages since the year 2005, as presented in Table 1.

Table 1.

Nuptials contracted in Spain in the years 1996-2014.

\begin{tabular}{|c|c|c|c|c|c|}
\hline Year & $\begin{array}{c}\text { Heterosexual } \\
\text { nuptials }\end{array}$ & $\begin{array}{c}\text { Nuptials } \\
\text { contracted } \\
\text { between men }\end{array}$ & $\begin{array}{c}\text { Nuptials } \\
\text { contracted } \\
\text { between women }\end{array}$ & $\begin{array}{c}\text { Same-sex } \\
\text { nuptials } \\
\text { (aggregated) }\end{array}$ & $\begin{array}{c}\text { Nuptials } \\
\text { (total) }\end{array}$ \\
\hline 1996 & 194.084 & 0 & 0 & 0 & 194.084 \\
\hline 1997 & 196.499 & 0 & 0 & 0 & 196.499 \\
\hline 1998 & 207.041 & 0 & 0 & 0 & 207.041 \\
\hline 1999 & 208.129 & 0 & 0 & 0 & 208.129 \\
\hline 2000 & 216.451 & 0 & 0 & 0 & 216.451 \\
\hline 2001 & 208.057 & 0 & 0 & 0 & 208.057 \\
\hline 2002 & 211.522 & 0 & 0 & 0 & 211.522 \\
\hline 2003 & 212.300 & 0 & 0 & 0 & 212.300 \\
\hline 2004 & 216.149 & 0 & 0 & 0 & 216.149 \\
\hline 2005 & 208.146 & 914 & 355 & 1.269 & 209.415 \\
\hline 2006 & 203.453 & 3000 & 1.313 & 4.313 & 207.766 \\
\hline 2007 & 201.579 & 2.141 & 1.052 & 3.193 & 204.772 \\
\hline 2008 & 194.022 & 2.051 & 1.143 & 3.194 & 197.216 \\
\hline 2009 & 174.062 & 1.984 & 1.098 & 3.082 & 177.144 \\
\hline 2010 & 167.247 & 1.955 & 1.238 & 3.193 & 170.440 \\
\hline 2011 & 159.798 & 2.073 & 1.467 & 3.540 & 163.338 \\
\hline 2012 & 165.101 & 1.935 & 1.520 & 3.455 & 168.556 \\
\hline 2013 & 153.375 & 1.648 & 1.423 & 3.071 & 156.446 \\
\hline 2014 & 159.279 & 1.679 & 1.596 & 3.275 & 162.554 \\
\hline
\end{tabular}

Source: INE 2016b, Fenómenos demográficos. Movimiento Natural de la Población, La Estadística de Matrimonios, i.e. Demographic phenomena. Natural movement of population. The Statistics of Nuptials. Tables from the years 1996-2014. 
When it comes to marriages contracted in Spain with at least one spouse being a foreigner, their numbers have been gradually increasing which is the opposite trend as compared to the total number of nuptials. While in the year 1996 only 9.198 marriages were contracted in Spain with at least one spouse being a foreigner, in the following years their numbers grew, until the year 2009 when they reached as many as 37.119. Subsequently, these numbers declined and in the year 2014 amounted to 25.804, but still remained much higher than in the mid-1990s, as presented in Table 2.

Table 2 .

Nuptials contracted in Spain in the years 1996-2014 with at least one spouse being a foreigner.

\begin{tabular}{|c|c|c|c|c|c|}
\hline Year & $\begin{array}{c}\text { Heterosexual } \\
\text { nuptials with } \\
\text { at least one } \\
\text { spouse being } \\
\text { a foreigner }\end{array}$ & $\begin{array}{c}\text { Nuptials } \\
\text { contracted } \\
\text { between men } \\
\text { with at least one } \\
\text { spouse being } \\
\text { a foreigner }\end{array}$ & $\begin{array}{c}\text { Nuptials } \\
\text { contracted } \\
\text { between women } \\
\text { with at least one } \\
\text { spouse being } \\
\text { a foreigner }\end{array}$ & $\begin{array}{l}\text { Same-sex } \\
\text { nuptials with } \\
\text { at least one } \\
\text { spouse being } \\
\text { a foreigner } \\
\text { (aggregated) }\end{array}$ & $\begin{array}{l}\text { Nuptials with } \\
\text { at least one } \\
\text { spouse being } \\
\text { a foreigner } \\
\text { (total) }\end{array}$ \\
\hline 1996 & 9.198 & 0 & 0 & 0 & 9.198 \\
\hline 1997 & 9.115 & 0 & 0 & 0 & 9.115 \\
\hline 1998 & 10.411 & 0 & 0 & 0 & 10.411 \\
\hline 1999 & 11.259 & 0 & 0 & 0 & 11.259 \\
\hline 2000 & 11.794 & 0 & 0 & 0 & 11.794 \\
\hline 2001 & 14.094 & 0 & 0 & 0 & 14.094 \\
\hline 2002 & 18.460 & 0 & 0 & 0 & 18.460 \\
\hline 2003 & 26.082 & 0 & 0 & 0 & 26.082 \\
\hline 2004 & 30.930 & 0 & 0 & 0 & 30.930 \\
\hline 2005 & 29.604 & 252 & 69 & 321 & 29.925 \\
\hline 2006 & 31.884 & 1.072 & 251 & 1.323 & 33.207 \\
\hline 2007 & 34.223 & 975 & 288 & 1.263 & 35.486 \\
\hline 2008 & 36.320 & 1.137 & 331 & 1.468 & 37.788 \\
\hline 2009 & 37.119 & 1.151 & 367 & 1.518 & 38.637 \\
\hline 2010 & 35.090 & 1.123 & 396 & 1.519 & 36.609 \\
\hline 2011 & 31.686 & 1.069 & 363 & 1.432 & 33.118 \\
\hline 2012 & 29.488 & 875 & 341 & 1.216 & 30.704 \\
\hline 2013 & 27.721 & 698 & 291 & 989 & 28.710 \\
\hline 2014 & 25.804 & 676 & 284 & 980 & 26.764 \\
\hline
\end{tabular}

Source: INE 2016b, Fenómenos demográficos. Movimiento Natural de la Población, La Estadística de Matrimonios, i.e. Demographic phenomena. Natural movement of population. The Statistics of Nuptials. Tables from the years 1996-2014. 
The decrease in the numbers of marriages contracted in Spain with at least one spouse being a foreigner is due to a number of factors including (1) naturalization of immigrants which officially puts them in the category of Spanish citizens instead of foreigners and (2) an economic crisis which started in the year 2008 and brought severe consequences in the subsequent years. It has not only decreased immigration inflows to Spain but also led to the search of other destinations or remigration of newcomers to their countries of origin. In the case of Latin Americans, including large numbers of Ecuadorians and Colombians, who had been keenly migrating to Spain and settling there before the crisis, it has become a commonly chosen solution. An accompanying trend is emigration of Spanish citizens either to other European countries, mostly the United Kingdom, France and Germany or to Latin America, including Brazil, Peru, Chile and Ecuador, which are currently on an upward growth curve. The growing unemployment rate which on the national scale reached over 20 per cent from the year 2010 onwards with a peak of 25,77 per cent which appeared two years later, daily hardship and a gloomy social atmosphere with respect to the future, do not provide incentives for settling down. Nonetheless, when observed in the entire time-span when such data are available, both the numbers of marriages contracted with at least one spouse being a foreigner and their share in the total number of nuptials have increased substantially.

When only data concerning heterosexual marriages are analyzed, in the year 1996 the ones contracted with at least one spouse being a foreigner constituted less than 5 per cent of the total number of different-sex marriages contracted in Spain. However, the proportion changed dramatically in the following years. In the year 2003 they amounted to over 12.2 per cent, in the year $2004-14.9$ per cent, in the year 2005 - 14.2 per cent, 2006 - 15.6 per cent, 2007 - 16.9 per cent and in $2008-18.7$ per cent. In the year 2009 they peaked to 21,3 per cent and remained high, having reached just below 21 per cent in the year 2010 and almost 20 per cent in the following year. There has been a noticeable downward trend, as in the year 2012 they amounted to 17.9 per cent, 2013 - 18.1 per cent and in the year 2014 16.2 per cent. When gender of the spouses is not taken into consideration, the share of marriages contracted with at least one spouse being a foreigner in the total number of nuptials is not drastically different and a similar trend is observable.

\section{Marriage and nationality in different-sex marriages}

This section presents detailed data on different-sex marriages contracted with at least one spouse being a foreigner with respect to the nationality of the spouses for the year 2014. These are the most recent statistics available at the time of writing this paper. I am leaving aside exhaustive data with respect to the nationality of the spouses concerning gay and lesbian marriages. Although there has been 
an upward trend concerning their numbers, as they constitute just a share in the overall number of nuptials, the ones referring to particular nationalities might not be of special interest to the reader. If one looks at the aggregated data concerning the continent of origin of the wife or the husband in heterosexual marriages contracted in Spain with at least one spouse being a foreigner, most of them are from Europe or the Americas, with a small proportion of the newly-wed originating from Africa or Asia.

When it comes to the continent of their origin, 17.193 wives - and this number constitutes a vast majority - are from Europe, 5.127 from the Americas, 2.782 from Africa, only 650 from Asia and 52 from the countries belonging to other continents (unclassified). The European nationalities which prevail are: Italian - 812, British 619, French - 483, German - 451, Romanian - 450, Irish - 313, Portuguese - 279, Ukrainian - 157, Dutch - 151 and Belgian - 118. When it comes to the country of origin in the Americas the largest numbers are from: Colombia - 823, Ecuador 703, Bolivia - 563, the Dominican Republic - 489, Argentina - 473, Brazil - 265, Cuba - 264, Peru - 252, the United States - 157, Uruguay - likewise 157, Chile 133 and Mexico - 122. In that category, most wives are from South America, with a much smaller proportion from Central America and even less from the United States. With respect to Africa the largest numbers are from Morocco - 1572, then Senegal - 292, Nigeria - 281 and Algeria - 185. Numbers of wives from Asia are substantially smaller, with Pakistani as the prevailing nationality which amounts to 295 nuptials, while others, including Indian, Chinese, Filipino are minuscule.

With respect to the numbers of husbands by their continent of origin, 15.122 are from Europe, 8.473 from the Americas, 1.653 from Africa, 532 from Asia and 24 from other continents (unclassified). The European nationalities of the husbands which prevail are: Spanish - 8.818, Russian - 804, Ukrainian - 479, British - 466, Italian - 426, German - 366, Polish - 351, French - 320, Irish - 292, Bulgarian 195 , Portuguese -173 and Dutch -120 . When it comes to precise data concerning the Americas as the continent of the husbands' origin, the dominating countries are: Colombia - 1.145, Brazil - 969, Bolivia - 830, Paraguay - 768, the Dominican Republic - 687, Ecuador - 640, Honduras - 530, Venezuela - 480, Argentina - 466, Peru - 374, Cuba - 344, Mexico - 296, Uruguay - 183, the United States - 181 and Chile - 176. The overall numbers of husbands who originate from Africa are generally smaller, with Morocco being a striking exception - likewise in the previous years. The numbers for Morocco are 1.180 nuptials contracted in that year, with a minor share of husbands from Algeria, Equatorial Guinea and even less from other countries on the continent. While Algeria is relatively close in geographical terms but quite far in terms of cultural factors ${ }^{10}$, Equatorial Guinea is much farther

${ }_{10}$ Algeria experienced of period of Spanish expansion but with little effect in terms of the ability to maintain power and minor cultural influence. Several towns and outposts were occupied by the 
in terms of the physical distance but has had substantial links with Spain due to its colonization ${ }^{11}$. When it comes to Asia, the largest number was for China - 167, with insignificant numbers of nuptials contracted by men from Japan, the Philippines and other Asian countries.

A large difference in the proportion between European countries and other continents results from the obvious fact that many of the spouses contracting a marriage where at least one of the spouses is a foreigner are Spanish themselves. When it comes to intermarriage of Spaniards with a foreign spouse, the total number of Spanish women who contracted a marriage in the year 2014 with a foreign husband amounted to 8.818 while a total of Spanish men who contracted a marriage in that year with a foreign wife was substantially bigger and amounted to 12.667 .

When it comes to the locations where the nuptials with at least one spouse being a foreigner are contracted, they take place mostly in Madrid, Barcelona, the Mediterranean coast, the Balearic Islands and the Canary Islands - this is where the rates of immigration have been the most significant. In the year 2014 the exact figures (by provinces) were: Madrid - 4.493, Barcelona - 4.270, Valencia - 1627, Alicante - 1.240, the Balearic Islands - 1.033, Malaga - 1027, Gerona - 727, Las Palmas - 622, Santa Cruz de Tenerife - 616, Seville - 521, Tarragona - 529. On top of the ones which took place in Spain, 1442 different-sex marriages of a Spanish citizen with a foreigner were contracted abroad.

\section{Conclusions}

When one compares the data concerning the total number of nuptials which are contracted in Spain and the ones where at least one of the spouses is a foreigner, reverse trends are observable. While there is a systematic decline in the overall number of marriages which are contracted, there was a clear upward trend until the late 2000s in the number of the marriages where at least one of the spouses was

Spanish between the early 16th and 18th centuries but it is France that eventually proved victorious. The colonial legacy is an important factor which has contributed to the fact that large numbers of Algerians migrated to France rather than Spain.

${ }^{11}$ Equatorial Guinea is an interesting phenomenon in terms of migration and the relations it has had with Spain in terms of the culture and politics. It is a former Spanish dominion and the only country in Africa where Spanish has the status of an official language, albeit it is nowadays mostly spoken by the elites. Having been taken over from Portugal, its territories became a Spanish colony. Further on, in the process of partial decolonization they were granted more convenient forms of dependence and became Spanish provinces. Spanish dominion in the region lasted until as late as the year 1968 when Spain conceded the independence of the Republic of Equatorial Guinea. Due to the colonial legacy there are still some socio-cultural and political links between the two countries and Spain is one of the places of migration and political exile for its citizens. 
a foreigner. The absolute numbers of such nuptials peaked in the year 2009 when they reached 37.119. Later on, there was a downward trend, albeit not radical as observed until the year 2014. The decrease in the number of marriages contracted with at least one spouse being a foreigner can be attributed to several factors. These include a change in the migration rate due to the economic crisis which made Spain less attractive as a host country for newcomers. Naturalization, i.e. the fact that many foreigners obtain Spanish citizenship should also be taken into account as it also has an impact on the statistics. That is to say, upon contracting a marriage they are classified as Spanish.

There are a number of other issues in transnational family formation that may be analyzed. Those include cohabitation, family reintegration, adoption, divorces and separations involving foreigners. What is important, due to the immigration processes the social fabric of Spain has undergone a radical change. Even if the rate of immigration will continue to decrease, there are large numbers of citizens who are not first-generation immigrants but their descendants.

\section{References}

Ai-hsuan, S.M. (2000), Rethinking Decision Making in Contemporary Migration Theories. Journal of National Chengchi Sociology, 30: 145-184.

Arrese Iriondo, M.N. (2010), El derecho de la reagrupación familiar tras la entrada en vigor de la Ley Orgánica 2/2009. Revista Vasca de Administración Pública/Herri-Arduralaritzako Euskal Aldizkaria, 87-88: 79-107.

Baldassar, L., Merla, L. (2014), Transnational Families, Migration and the Circulation of Care: Understanding Mobility and Absence in Family Life, Abingdon, Oxon, New York: Routledge.

Beck, U., Beck-Gernshein, E. (2014), Distant Love. Personal Love in the Global Age, Cambridge, Malden: Polity Press.

Bell J., Erdal M.B. (2015). Limited but Enduring Transnational Ties? Transnational Family Life Among Polish Migrants in Norway. Studia Migracyjne - Przeglad Polonijny, 41(3): 77-98.

Bryceson, D.F., Vuorela, U. eds. (2002), The Transnational Family: New European Frontiers and Global Networks. Oxford: Berg Publishers.

Francisco-Menchavez, V. (2018), The Labor of Care: Filipina Migrants and Transnational Families in the Digital Age, Champaign: University of Illinois Press.

Freire Correia de Gusmao, A.C. (2010), El derecho a la reagrupación familiar en el Derecho español y comunitario. Revista de Derecho Migratorio y Extranjería, 23: 113-160.

Goulbourne, H., Reynolds, T., Solomos, J., Zontini, E. (2010), Transnational Families: Ethnicities, Identities and Social Capital, Abingdon, Oxon, New York: Routledge.

Gozálvez Pérez, V. (2012), La reagrupación familiar de extranjeros en España. Nueva Revista de Política, Cultura y Arte, 138: 150-162.

Heidbrink, L. (2014), Migrant Youth, Transnational Families, and the State: Care and Contested Interests, Philadelphia: University of Pennsylvania Press.

Hărăguș, M., Telegdi-Csetri, V. (2018), Intergenerational Solidarity in Romanian Transnational Families, in: Crespi I., Meda S.G., Merla L., eds., Making Multicultural Families in Europe. Gender and Intergenerational Relations, Cham: Palgrave Macmillan, p. 161-177. 
Hirsch, J.S. (2003), A Courtship After Marriage: Sexuality and Love in Mexican Transnational Families, Berkeley, Los Angeles, London: University of California Press.

Kaczmarczyk, P., Stanek, M. (2016), Crisis and Beyond: Intra-EU Mobility of Polish and Spanish Migrants in a Comparative Perspective, in: Triandafyllidou, A., Isaakyan, I., eds., High Skill Migration and Recession: Gendered Perspectives, Basingstoke: Palgrave Macmillan, p. $69-100$.

Johnson, C.H., Sabean, D.W., Teuscher, S., Trivellato F., eds. (2011), Transregional and Transnational Families in Europe and Beyond, Experiences Since the Middle Ages, New York, Oxford: Berghahn Books.

La Spina, E. (2011), Familias transnacionales, sociedades multiculturales e integración. España, Italia y Portugal en perspectiva comparada. Madrid: Editorial Dykinson.

Lee, E.S. (1966). A theory of migration. Demography, 3 (1): 47-57.

Madianou, M, Miller, D. (2012), Migration and New Media: Transnational Families and Polymedia, Abingdon, Oxon, New York: Routledge.

Martín Villegas, A. (2015), El derecho de reagrupación familiar en España. Retos y perspectivas. Revista de Derecho Migratorio y Extranjería, 38: 39-55.

Orellana, M.F., Thorne B., Chee A., Lam W.S.E. (2001), Transnational Childhoods: The Participation of Children in Processes of Family Migration. Social Problems 48(4): 572-591.

Pérez-Nievas Montiel, S., Vintila, C.D. (2011), La reagrupación familiar en España y en Europa. Anuario de la Facultad de Derecho de la Universidad Autónoma de Madrid, 15: 143-169.

Salazar Parreñas, R. (2005), Children of Global Migration: Transnational Families and Gendered Woes, Stanford: Stanford University Press.

Schmalzbauer, L., (2005), Striving and Surviving: A Daily Life Analysis of Honduran Transnational Families, New York: Routledge.

Slany, K., Ślusarczyk, M., Pustułka, P., Guribye, E. (2018), Transnational Polish Families in Norway: Social Capital, Integration, Institutions and Care, Frankfurt am Main: Peter Lang.

Sportel, I. (2016), Divorce in Transnational Families: Marriage, Migration and Family Law, Basel: Palgrave Macmillan/Springer International Publishing AG.

Tyrrell N., White A., Ní Laoire, C., Carpena-Méndez F., eds. (2013), Transnational Migration and Childhood. New York: Routledge.

Yarris, K.E. (2017), Care Across Generations: Solidarity and Sacrifice in Transnational Families, Stanford: Stanford University Press.

Zontini, E. (2010), Transnational families, migration and gender: Moroccan and Filipino women in Bologna and Barcelona, New York: Berghahn Books.

\section{Other sources:}

INE (2016a). Avance de la Estadística del Padrón Continuo a 1 de enero de 2016, Datos provisionales, press release as of the 28th of April, p.1-18. http://www.ine.es/prensa/np966.pdf. [Date of access 9.08.2016].

INE (2016b), Fenómenos demográficos. Movimiento Natural de la Población, La Estadística de Matrimonios, i.e. Demographic phenomena. Natural movement of population. The Statistics of Nuptials. tables from the years 1996-2014.

http://www.ine.es/jaxi/menu.do?type=pcaxis\&path=/t20/e302\&file=inebase. [Date of access 9.08.2016].

The Law 4/2000, as of the 11th of January, on the rights and liberties of foreigners in Spain and their social integration (Ley Orgánica 4/2000, de 11 de enero, sobre derechos y libertades 
de los extranjeros en España y su integración social), BOE (Boletín Oficial del Estado), number 10,12/01/2000, Valid since: 01/02/2000, with amendments. https://www.boe.es/buscar/ act.php?id=BOE-A-2000-544. [Date of access 9.08.2016].

The Law 13/2000, as of the 13th of July which amends the Spanish Civil Code with respect to the right to marry (Ley 13/2005, de 1 de julio, por la que se modifica el Código Civil en materia de derecho a contraer matrimonio), BOE (Boletín Oficial del Estado), number 157, 2/07/2005. https://www.boe.es/buscar/doc.php?id=BOE-A-2005-11364. [Date of access 9.08.2016]. 